\title{
Informality and the Education Factor in Indonesian Labor
}

\author{
${ }^{*}$ Setyanti, Axellina Muara \\ ${ }^{* 1}$ Department of Economics, Brawijaya University
}

\begin{tabular}{l}
\hline \hline ARTICLE DETAILS \\
\hline Article History \\
Published Online: \\
JIAE (Journal of Indonesian Applied \\
Economic)
\end{tabular}

\section{Keywords}

Informal workers, Informal Sector, Employment, Education

\section{*Corresponding Author}

Email: axellinamuara@ub.ac.id

\begin{abstract}
Informal sector plays a major role in Indonesia. In 2018, this sector generates 57,9 percent employment of the total workforce. Moreover, Small and Medium Enterprises (SMEs), one of the biggest pockets of informal workers account 64.19 million business units and contributes 99,99 percent to the total business units in Indonesia. Using the data from Survei Angkatan Kerja Nasional (Sakernas) 2018, this study aimed to identify the characteristics of informal workers in Indonesia and to understand does the informality vary across the workers' education level. The results show that the higher of workers' education, they are less likely to work in informal sector. Group of people who have higher probability to work informally are those who live in rural, women, elderly, have less household members, have primary to secondary education background, and not holding training certificate. The informal sector should get a particular attention from policy makers so it can improve working conditions to make better employment that offer greater economic inclusion, generate higher income, and create pathways out of poverty.
\end{abstract}

\section{INTRODUCTION}

The informal economy plays a major role in employment creation, income and production generation in many countries (ILO, 2013). According to the most recent data released by the International Labor Organization (ILO, 2018), close to two billion people world-wide are employed in the informal economy. This constitutes nearly 60 percent of the world's working population. When agriculture is not taken into consideration, this figure goes down to 50 percent, which is still a significant amount (Petrova, 2019).

Since the 1970's Indonesia has experienced an era of high economic growth accompanied by a shift in economic structure from the agricultural to non-agricultural sectors. Because the agricultural sector is generally located in rural areas while non-agriculture, mainly industry, is located in urban areas, there is a flow of labor migration to the city along the process of industrialization, with various push and pull factors. Interestingly, the movement of workers from villages to cities is accompanied by a large number of workers entering the small business sector because not all of them are able to enter the industrial sector. This migration is one of the main causes of the development of the informal sector (Bappenas, 2009).

In Indonesia the average percentage of informal workers in 34 provinces was 57.9 percent in 2018. The provinces with the highest percentage of informal workers were Papua (77.63 percent) and the lowest was DKI Jakarta (30.18 percent) (BPS, 2018). So, the existence of a large informal sector in Indonesia is still employ most of the workforce in Indonesia. One of the biggest pockets of informal workers is Small and Medium Enterprises (SMEs). At present there are more than 64.19 million business units in Indonesia, growing $2.02 \%$ from the previous year. This number has a $99.99 \%$ share of the total business units in Indonesia (Kemenkop and UKM, 2018).

These numbers continue to grow because SMEs are considered to have several advantages such as producing consumer goods and services that are close to the needs of the community, SMEs do not rely on imported raw materials and rather utilize local resources both 
in terms of human resources, capital, raw materials, and equipment and SMEs in general, using their own capital although small and does not depend on loans from banks. With these advantages, SMEs in Indonesia are able to survive amid the economic crisis that hit Indonesia. Although it has several advantages, SMEs have many limitations. This limitation makes it difficult for SMEs to develop and become competitive (BPS, 2019). Work in the informal sector tends to be easier to obtain, but is vulnerable to work risks due to unprotected workers (Hohberg \& Lay, 2015).

ILO defines the informal economy acknowledges not only unregistered and unrecognized firms, but also workers who are in an uncertain and volatile situation (ILO, 2013). In other words, the informal economy includes both the informal sector and informal employment. Informal employment is a broader concept which also includes employment of an informal nature in formal enterprises, as well as wage and selfemployment in informal enterprises and household businesses (Hieu et al., 2014). While some define informal sector as a very small enterprises that use low-technology models, unincorporated, and unregistered (Kar \& Marjit, 2009; Brown \& Roever, 2017).

About the role of informal sector, many literatures believe that informal sector provides a safety net for those excluded and incapable to enter the formal economy, while others argue that it provides supplementary employment for those in the formal sector. The implication is that informal work is done principally by people of low socioeconomic status and serves as a safety net for the poor (Losly et al., 2002). Some said it also related to rural-urban migration that the surplus of rural agricultural labor force them to migrate to cities in search of a better livelihood. Informal economy is considered the fastest and easiest way to enter as a temporary destination before moving on to the formal sector. So, informal sector is considered only as a stepping stone or transition sector (Noeraini, 2015). Contrarily, Bappenas (2009) states that informal sector is not a transition sector, but a destination of the job-seekers from traditional/agricultural sector and the first job-seekers who are not accommodated in the formal sector. That is why informal sector are closely related to those who low educated and unskilled.

Using the data from Survei Angkatan Kerja Nasional (Sakernas) 2018 and probit regression method we aimed to catch the individual level data and analysis. Thus, the objectives of this study are: 1) to identify the characteristics of informal workers in Indonesia; and 2) to understand does the informality vary across the workers' education level.

\section{LITERATURE REVIEW}

Begin with the division of economic activity to traditional and modern sector, dualistic approach has become theoretical basis in most of literature in the neoclassical view, especially in the third world economies. In the beginning of 1970's, Hart in Bromley (1979) presented a paper about urban occupation and introduced the term 'informal' such an extension of traditional sector and 'formal' closely related to modern sector. Informal sector emphasized on self-employment, and small enterprise.

The informal sector was defined by the 15th International Conference of Labour Statisticians (ICLS) (ILO, 1993 in Charmes, 2012), referred to the characteristics of the economic units in which the persons work. Some of the aspects are legal status (individual unincorporated enterprises of the household sector), registration of the economic unit or of its employees that mostly in informal sector are unregistered; size of employment that is under five permanent paid employees; and the production for the market. Furthermore, in ILO (2018) the informal sector is enterprises that are owned by individual household members or several members of the same or different households. typically, they are operating at a low level of organization, on a small scale and with little or no division between labour and capital as factors of production.

In contrast to the concept of the informal sector that refers to production units as observation units, the concept of informal employment refers to jobs as observation units (Ilo, 2003; Hussmanns, 2004). In the case of own-account workers and employers, the informal employment status of the job is determined by the informal sector nature of the enterprise. Thus, own-account workers without hired workers that operating an informal enterprise are classified as in informal employment. Similarly, employers with hired workers that operating an informal enterprise are classified as in informal employment. All contributing family workers are classified as having informal employment, irrespective of whether they work in formal or informal sector enterprises.

Within informal employment, there is considerable diversity in terms of occupational groups and activities. The informal workforce is comprised primarily of construction workers, domestic workers, home-based producers, street vendors, transport workers, waste pickers, and informal employees, some of whom work in sweatshops or other hazardous work environments. Those workers have in common a 


\section{The Analysis of Informal Workers in Indonesia}

lack of adequate labour protections and access to social protection schemes. Earnings are, on average, low and unstable. Many also live in informal settlements with inadequate basic services, so their exposure to risk is high (Brown \& Roever, 2017).

Related to formal-informal labour market, the labour market might allow the workers to choose, to decide for themselves, in line with neoclassical thinking, but here the range of options is determined by the constraints imposed by the demand side. This alternative perspective is not that labour demand is broad and diverse, as is assumed in neoclassical theory, but on the contrary, that there are restrictions on jobs, primarily formal jobs, as the modern sector only demands the jobs that it needs (Uribe \& Ortiz, 2006; Uribe, Ortiz \& García, 2007; Garcia \& Badillo, 2017). Because there are restrictions on the number of jobs, the decision of wanting to work does not necessarily mean the individual will be contracted; that is, the probability of wanting a job in a given sector is not equal to the probability of being employed in that sector.

In the Harris-Todaro (1970) model, the primary sector represents the formal sector and the secondary sector is the informal sector, and the latter sector arises as a consequence of fixing wages above the market-clearing rate, which can lead to unemployment in equilibrium, where unemployment goes undercover in the informal sector. The existence of higher wages in the formal sector may attract workers from the informal sector who may not find a position in the formal sector due to formal jobs rationing in the economy. This leads to a formal sector queuing and informality acts as an escape from unemployment.

While according to the underground approach in Pitoyo (2007), the informal sector grows as a result of international competition among the world's major industries. The largescale industry is more in control of the market and henceforth is known as the formal sector. The existence of large-scale industry naturally will grow a lot of small industries so that various forms of competition will emerge. This competition will force small industries to carry out various informal activities to survive. In the next stage there will be many informal activities, both institutions and medium scale industries, which support large industries in the world economic competition.

\section{METHOD}

The data source used in the study was from the 2018 National Labor Force Survey (Sakernas) conducted by Central Bureau of
Statistics (BPS). Sakernas data is a micro data that illustrates the general state of employment as well as shifts in employment structure between periods of enumeration. In general, the labor data collection period is done twice a year. Sakernas data is used in this study because it is able to capture the conditions of individual employment in Indonesia, including the education level of informal sector workers.

BPS basically divides the main employment status of workers into seven categories: 1) Selfemployed; 2) Trying to be assisted by temporary workers / family workers / unpaid; 3) Trying to be assisted by permanent / paid workers; 4) Workers / employees / employees; 5) Free labor on agriculture; 6) Non-agricultural free workers; 7) Family worker / unpaid. Categories 2, 3, 4 can be classified into Formal Workers, while categories 1, 5, 6, 7 are classified into Informal Workers.

After filtering the data, a total sample of 314,436 people was obtained, consisting of 176,125 formal workers and 138,311 informal workers. This research pretty much describes the conditions of informal workers in Indonesia in a descriptive manner, for example demographic characteristics, socioeconomic, and so on. Then to answer the research problem formulation, Probit regression is used to determine the trend of income of informal workers plus some individual characteristics using binary dependent variables: Informal Workers are valued by 1 and formal workers are valued by 0 . Probit regression analysis can be explained by the following equation:

$$
\begin{aligned}
& \text { Informal }_{i t} \\
& =\beta_{0}+\beta_{1} \text { Rural }_{i}+\beta_{2} \text { Male }_{i}+\beta_{3} \text { Age }_{i} \\
& +\beta_{4} \text { Agesquare }_{i}+\beta_{5} \text { HH_members }_{i} \\
& +\beta_{6} \text { Primary_edu }_{i}+\beta_{7} \text { Secondary_edu }_{i} \\
& +\beta_{8} \text { Training }_{i}+e
\end{aligned}
$$

Where,

Informal: Informality status (1=informal ; $0=$ formal)

Rural : Location (1=rural ; $0=$ urban)

Male : Gender ( $1=$ male $; 0=$ female $)$

Age : Age of worker

Agesquare: Age of worker square

$\mathrm{HH}$ _members: Number of household members

Primary_edu: Worker's education (1=primary ; $0=$ others)

Secondary_edu: Worker's education ( $1=$ secondary $; 0=$ others)

Training: Training certificate ownership (1=have ; $0=$ don't have)

i : individual-i

e : error

Faculty of Economics and Business, 


\section{RESULT AND DISCUSSION}

Informal workers are all too often seen simply as vulnerable and unproductive workers trapped in a cycle of poverty. A better understanding of the role of informal employment in actually reducing poverty - rather than perpetuating it - could influence a new generation of policies that recognize and support the role of earnings from informal employment in the households (Rogan and Cichello, 2017).

There is a perspective called revolution stated that poverty alleviation occurs when entrepreneurship in informal economy introduces alternatives to capitalism as it is said to have some of the basic assumptions of capitalism such as economic self-interest, efficiency, and an individualistic orientation (Calas et al., 2009; Peredo and Chrisman, 2006). Based on Nepal's experiences, Aagarwal and Dhakal (2010) suggest that the informal sector is a good source of livelihood for poor and marginalized groups. They prove that earnings from the informal sector have been making a strong impact on the households' livelihood.

The conditions of informal workers in Indonesia lately can be illustrated by the following graphs. First, comparing their location, informal workers are dominated by people who are living in rural areas. From all informal workers in Indonesia, 87.410 people or around $63 \%$ of workers are living in rural areas, compared to 50.901 people or $37 \%$ of workers from urban areas.

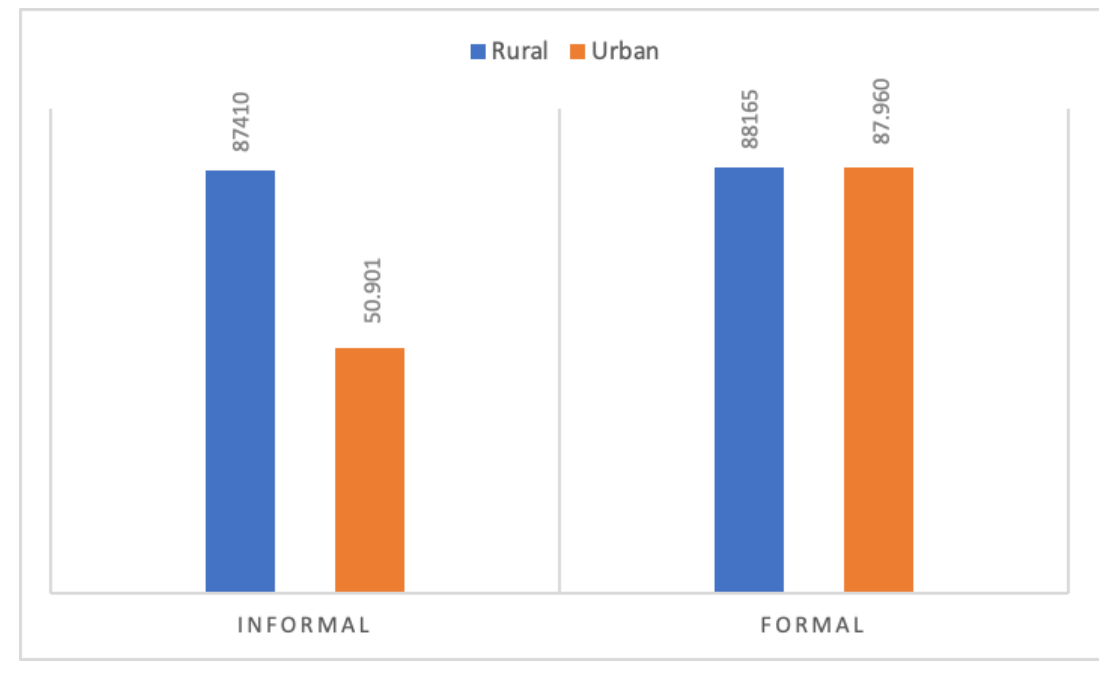

Picture 1. Workers Based on Location

Source: Sakernas 2018 (processed)

In rural areas, the informal economy sustains livelihoods of impoverished populations through natural resource and land based economic activities such as farming, logging and mining (Weng, 2015). In Ikhsan (2005) and Noeraini (2015) analysis, the informal sector controls $2 / 3$ of total employment and around 80 percent are in rural areas and most informal workers are in the agricultural sector, although with a downward trend. On the other hand, The informal sector provides the possibility of excess labor in rural areas for migration from poverty and unemployment.

Nevertheless, the existence of formal and informal sectors in an economic system also will always coexist with one another, where there is a formal sector where there is an informal sector. Absolute poverty pressure causes rural populations to go to urban areas to meet their basic needs. But the formal sector gives only very little space compared to the flow of job seekers from rural areas. The existence of the formal sector in the city, for example offices or industry, will be followed by the rise of various informal sectors, such as street vendors and small services. The informal sector, whose economic activities provide important services to the urban community, functions to complement (or substitute) the formal sector (Pitoyo, 2007).

Next, comparing the gender, in the informal sector, the number of male and female workers is relatively balanced when compared to the formal sector which is more dominated by men. In the informal sector, the proportion of male workers was $50.6 \%$ while female workers were $49.4 \%$. In the formal sector the proportion of male and female workers was $65.6 \%$ and $34.4 \%$, respectively. 


\section{The Analysis of Informal Workers in Indonesia}

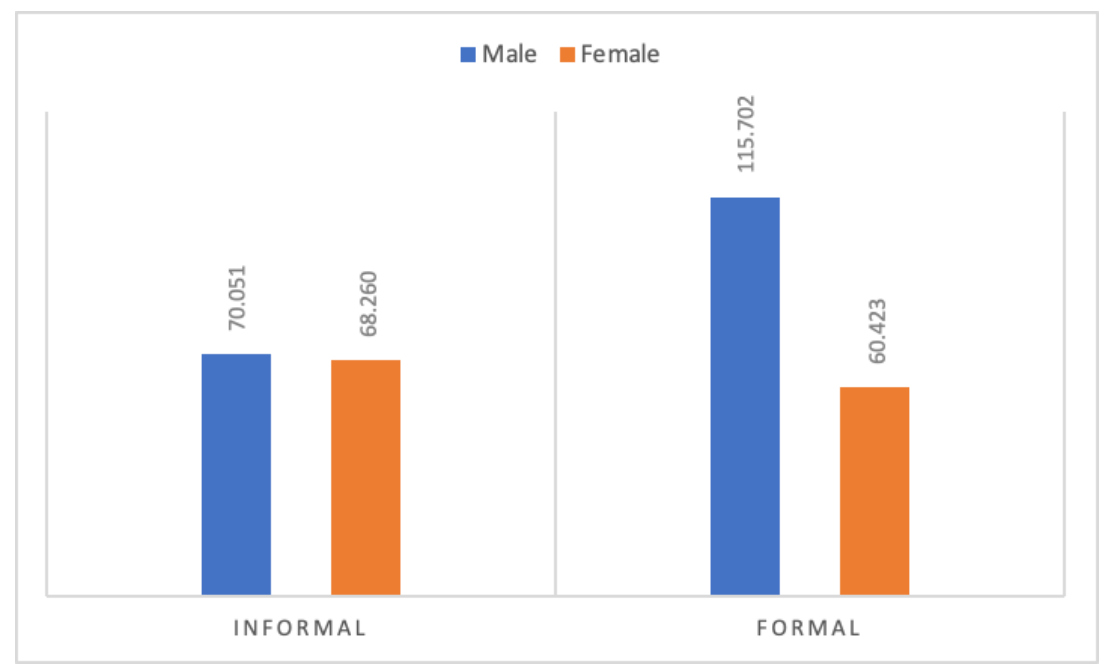

Picture 2. Workers Based on Gender

Source: Sakernas 2018 (processed)

Men and women in developing countries who are characterized by limited skills, low education and low status, the informal sector is the only arena in which they can attempt to eke out a living. In parallel there is a growing awareness of woman's exclusion from development plans and households that are female-headed were responsible for the needs of their families. This has led to an increasing emphasis of women's involvement informal sector programs (Jennings, 1993; Singh, 2009).

Somehow, women are remaining concentrated in invisible areas of informal work, such as domestic labour home-worker and assistance in small family enterprises, which offer precarious employment status, low, irregular or no remuneration, little or no access to social security or protection, and limited ability to organize. So they cannot ensure the enforcement of international labour standards and human rights (Chant and Pedwell, 2008; Carr and Chen, 2002).

The number of women who work is not paid, economically, women's services are considered family-based businesses but are very promising in economic development. Women who work as independent workers assisted by family members show that women have the potential to create jobs. The large number of women working in the informal sector shows that the role of women in the informal sector is very large in contributing to supporting the household economy (Nilakusmawati, 2009).

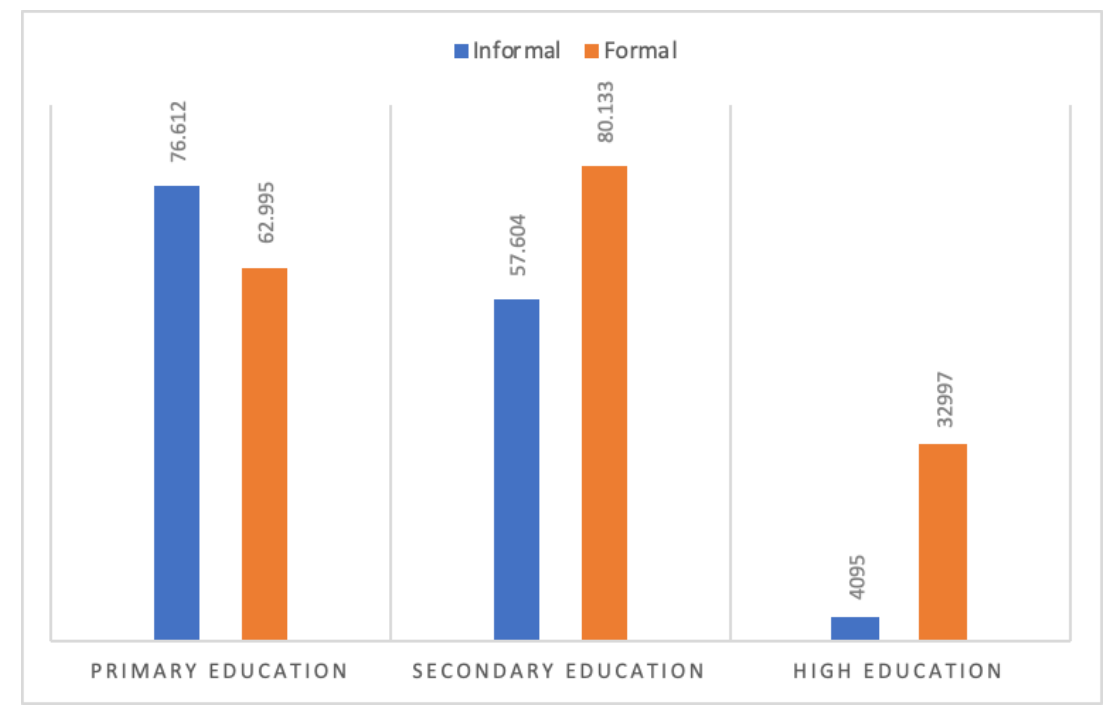

Picture 3. Workers Based on Education Level

Faculty of Economics and Business, Brawijaya University 
Picture 3 presents the profile of Indonesian informal worker based on their education background. The involvement in informal sector seems decline along with higher education level. In the primary education level, the proportion of informal to formal worker is $54,8 \%$ and $45,2 \%$ respectively. In the secondary education, the proportion of informal workers declines to $41,8 \%$. So does in high education level, the informal workers only account $11 \%$ of total workers.

In the field of education, people in the informal sector are characterized by low levels of formal schooling, high drop-out rates from school and lack of access to tertiary education (Singh, 2009). Education can help individuals develop employable skills and get access to new labor markets or even migrate to formal sector. However, societal or labor force discrimination could undo the returns to education for certain social groups by forcing members of nondominant groups into informal labor markets (Taymaz, 2009; UNDP, 2013; Montes et al, 2016).

Table 1. Probit Estimation to All Samples

\begin{tabular}{ccc}
\hline & Coef & $\mathbf{P}>|\mathbf{z}|$ \\
\hline Rural & $0,1713^{*}$ & 0,0000 \\
Male & $-0,4518^{*}$ & 0,0000 \\
Age & $-0,0290^{*}$ & 0,0000 \\
Agesquare & $0,0002^{*}$ & 0,0000 \\
HH_members & $-0,015^{*}$ & 0,0000 \\
Primary_edu & $1,2586^{*}$ & 0,0000 \\
Secondary_edu & $0,9857^{*}$ & 0,0000 \\
Training & $-0,3097^{*}$ & 0,0000 \\
Constant & $-0,2477$ & 0,0000 \\
Number of obs & 314.436 & \\
LR chi2(8) & 39007,74 & \\
Prob>chi2 & 0,0000 & \\
Pseudo R2 & 0,0904 & \\
\hline \multicolumn{2}{c}{ Source: Sakernas 2018 (processed) }
\end{tabular}

Note: *significant in $1 \%$ level of significance

As presented in Table 1, people who are living in rural areas are more likely to work in informal sector compared to people living in urban areas. This is in line with Picture 1 explaining the domination of informal workers are from rural areas. The informal sector is an alternative employment opportunity that is able to accommodate workers without certain requirements such as the level of education and work skills so that many are in accordance with rural communities who have relatively low levels of education. On the other hand, the informal sector in urban areas is also quite high because it gives the possibility of excess labor in the countryside for migration from poverty and unemployment.

Males are less likely to work in informal sector compared to females, indicated by a significant and negative coefficient. Women employees seem to have a relatively lower risk of being informal when working in non-standard forms of employment and notably when working part-time, moreover when that women as heads of household (ILO, 2018; Omom, 2017). In previous research, such as Wijayaningtyas (2017), found that informal workers were satisfied with their wage and work because of the flexibility of working hours. In many cases, formal-salaried workers are paid significantly higher than their informal counterparts and of the self-employed (Tansel \& Acar, 2016). As most men become head of household with economic responsibilities, working in the formal sector with income security can be an option. So, women have a higher tendency to work in the informal sector than men.

There is a non-linear relationship of ages, suggesting that the probability of working in informal sector decreases as age increases, but it will increase at a certain age. This is consistent with the findings of Noeraini (2015) where in the informal sector the percentage of workers tends 


\section{The Analysis of Informal Workers in Indonesia}

to increase with age. This shows that the informal sector can be entered by workers of any age group (low barrier to entry), so that it is always attractive to the workforce. And for those who are older than 60 years where their ability has declined and of course less able to compete, the informal sector is more friendly to enter.

Growing age of workers make higher productivity and it is needed in formal sector rather than informal sector. Furthermore, there will be a negative effect on value added per worker when the worker reaching a certain age. In Lee et al. (2018), it happened in the workers aged 50 years and over. Besides that, young workers are much more likely to transition across sectors. Also, it is typically the low earning workers of the formal sectors that fall to informality more easily, which it is the highearnings workers from the informal sector that most frequently switch to formal employment (Gomes, 2019). Next, workers with bigger number of household members are less likely to enter informal sector.

Related to workers' education, worker with primary education are more likely to choose informal jobs rather than those who have secondary education, indicated by bigger coefficient in primary education variable. In Nackerdien \& Yu (2019), older and more educated individuals living in urban areas are significantly more likely to work in the formal sector rather than informal sector.

Lastly, those who hold training certification are less likely to work in informal sector. Employment decisions are considered as being determined by factors of both supply and demand. Thus, although individuals have the opportunity to choose and to decide whether to work or not and to select the type of work they wish to perform, there are restrictions on the range of options available to them. These restrictions correspond to the limitations imposed by the demand side of the labour market, such as the few good quality jobs that are being created (Garcia \& Badillo, 2018). Then it makes what it called job queue. Those who hold training certification will have bigger opportunity to enter formal labor market and pass the queue than those who don't. While on the other hand, the informal sector also does not require complicated requirements for its workers.

Table 2 presents the estimation of Probit regression with separation on worker's level of education. The aim is to identify does the probability of workers vary across their education level.

Table 2. Probit Estimation Specificly to Workers' Education

\begin{tabular}{ccccccc}
\hline & \multicolumn{2}{c}{ Primary Education } & \multicolumn{2}{c}{ Secondary Education } & \multicolumn{2}{c}{ High Education } \\
\cline { 2 - 7 } & Coef & $\mathbf{P}>|\mathbf{z}|$ & Coef & $\mathbf{P}>|\mathbf{z}|$ & Coef & $\mathbf{P}>|\mathbf{z}|$ \\
\hline Rural & $0,831^{*}$ & 0,000 & $0,282^{*}$ & 0,000 & $-0,051^{*}$ & 0,006 \\
Male & $-0,613^{*}$ & 0,000 & $-0,386^{*}$ & 0,000 & $0,048^{*}$ & 0,006 \\
Age & $-0,035^{*}$ & 0,000 & $-0,042^{*}$ & 0,000 & $-0,074^{*}$ & 0,000 \\
Agesquare & $0,0003^{*}$ & 0,000 & $0,0005^{*}$ & 0,000 & $0,0008^{*}$ & 0,000 \\
HH_members & $-0,018^{*}$ & 0,000 & $-0,013^{*}$ & 0,000 & $-0,005$ & 0,317 \\
Training & $0,118^{*}$ & 0,000 & $0,335^{*}$ & 0,000 & $-0,298^{*}$ & 0,00000 \\
Constant & 1,416 & 0,000 & 0,807 & 0,000 & 0,319 & 0,002 \\
Number of obs & 139.607 & & 137.737 & & 37.092 & \\
LR chi2(8) & 8727,56 & & 6393,35 & & 515,58 & \\
Prob>chi2 & 0,0000 & & 0,0000 & & 0,0000 & \\
Pseudo R2 & 0,0454 & & 0,0341 & & 0,0200 & \\
\hline
\end{tabular}

Note: *significant in $1 \%$ level of significance

As presented above, workers who live in rural areas and have primary education are more likely to work in the informal sector compared to those with secondary education and high education. Those with higher education are the least likely to do informal jobs even though they all live in rural areas, indicated by a negative coefficient.

Interestingly, male workers with primary and secondary education are less likely to work informally. However, the workers are more likely to work informally when they are high educated. Based on age, the higher level of education a worker has, the less likely to work informally. However, after reaching a certain age, the tendency will reverse. The probability of working informally will increase for all primary educated, secondary educated, and highly educated 
categories.

For the variable number of household members, there is not too much difference between workers with primary, secondary, and high education indicated by a very small difference in coefficient. But all three categories of education have the same tendency, that workers are less likely to work informally when they have more household members. Finally, related to training, highly educated workers who hold training certificates are the least likely to work informally when compared to workers with primary and secondary education.

Finally, findings of this research support the theory that probability of mobility labor informal sector affected by the level of education, where labor informal sector with higher education choose not to work on the informal sector, while labor informal sector with low levels of education choose to stay work on the informal sector (Handayani et al.,2018). For those with low education, the informal sector is the only choice in maintaining life because they are very difficult to enter the formal sector (Noeraini, 2015).

\section{CONCLUSION}

Based on the descriptive and Probit estimation, the analysis shows that all of the characteristics are significant to the probability of worker to work informally. This study also finds that the higher of workers' education, they are less likely to work in informal sector. Group of people who have higher probability to work informally are those who live in rural, women, elderly (might be unproductive age), have less household members, have primary to secondary education background, and not holding training certificate.

We also figure out that informal sector has a big role to economics such as generating income and employment, but the socially unprotected, unproductive and underpaid workers in the informal economy should become a particular attention. Policy makers should be very conscious about this threat to create more adequate working condition in informal sector. The productivity in informal sector should be enhanced for example to enable informal enterprises to get recognition, improve working conditions so it makes better employment that offer greater economic inclusion to generate higher income and create pathways out of poverty.

The use of capital in the informal sector is relatively small when compared to the formal sector so that with small capital, the informal sector can create job opportunities. By providing strategic and targeted access to training and skills, the informal sector can have a large role in developing human resources. The future studies need to consider more detailed characteristic of informal job of the workers, such as the economic sector they came from. The different economic sectors, also different policies that need to be applied. Policy interventions in the informal economy also need to pay attention to regional and income group differences.

\section{REFERENCES}

Aagarwal, M Kumar. and Dhakal, R Chandra., (2010). Informal Sector And Income Generation In Nepal--A Case Of Chitwan District. Indian Journal of Labour Economics, 53(2).

Badan Perencanaan Pembangunan Nasional (Bappenas). (2009). Kajian Evaluasi Pembangunan Sektoral Peran Sektor Informal Sebagai Katup Pengaman Masalah Ketenagakerjaan. Jakarta: Kedeputian Evaluasi Kinerja Pembangunan Bappenas.

Badan Pusat Statistik (BPS). (2018). Persentase Pekerja Formal Menurut Provinsi 20152018. Jakarta: Badan Pusat Statistik.

Badan Pusat Statistik (BPS). (2019). Analisis Hasil SE2016 lanjutan Potensi Peningkatan Kinerja Usaha Mikro Kecil. Jakarta: Badan Pusat Statistik.

Bromley, R. (1978). Urban Informal Sector-Why Is It Worth Discussing-Introduction. Oxford: Pergamon Press.

Brown, A. M. B., \& Roever, S. (2017). Enhancing productivity in the urban informal economy. DFID-ESRC Joint Fund for Poverty Alleviation Research, RES-16725-059 Making Space for the Poor: Law, Rights, Regulation and Street-Trade in the 21st Century

Calás, M.B., Smircich, L. and Bourne, K.A., (2009). Extending the boundaries: Reframing "entrepreneurship as social change" through feminist perspectives. Academy of Management Review, 34(3), pp.552-569.

Carr, Marilyn and Chen, Martha (2002) Globalization and the Informal Economy: How Global Trade and Investment Impact on the Working Poor, Working Paper on the Informal Economy Working No. 1 INTEGRATION (Geneva: International Labour Office).

Chant, S., \& Pedwell, C. (2008). Women, gender and the informal economy: An assessment of ILO research and 
suggested ways forward. Geneva: ILO.

García, G. A., \& Badillo, E. R. (2018). Rationing of formal sector jobs and informality: The Colombian case. Journal of International Development, 30(5), 760-789.

Gomes, D., lachan, F., \& Santos, C. (2019). Labor earnings dynamics with a large informal sector. Meeting Papers Society for Economic Dynamics No. 793.

Handayani, G. A., Priyagus, P., \& Amalia, S. (2018). Analisis mobilitas tenaga kerja pada sektor informal. Jurnal IImu Ekonomi Mulawarman (JIEM), 2(4).

Hieu, N.T.M., Giang, N.T.H., Ngoc, V.T.M., Duc, N.V. and Quan, T.T., (2014). Does the informal economy mitigate poverty and how does it work?: the case of Vietnam. Retrieved

from https://pdfs.semanticscholar.org/6f59/a c412ffa852e820a7d40c6d5593023102 54 e.pdf on July 15 th 2020.

Hohberg, M., \& Lay, J. (2015). The impact of minimum wages on informal and formal labor market outcomes: evidence from Indonesia, IZA Journal of Labor \& Development, 4(1), 1-25.

Ikhsan, Mohamad, (2005), Peran Pasar Tenaga Kerja yang Fleksibel Dalam Mengatasi Pengangguran. LPEM Working Paper No. 11/2005. Lembaga Penyelidikan Ekonomi dan Masyarakat, Universitas Indonesia, Jakarta.

ILO. (2013). The Informal Economy and Decent Work: A Policy Resource Guide. Geneva: ILO.

----. (2018). Women and men in the informal economy: a statistical picture (third edition) / International Labour Office Geneva: ILO.

Jennings, M. (1993). Gender issues in the informal sector: constraints and opportunities. Trócaire Development Review, 49-66.

Kar, S., \& Marjit, S. (2009). Urban informal sector and poverty. International Review of Economics \& Finance, 18(4), 631-642.

Kementerian Koperasi dan Usaha Kecil dan Menengah (Kemenkop dan UKM). (2018). Perkembangan Data Usaha Mikro, Kecil, Menengah (UMKM) Dan Usaha Besar (UB) Tahun 2017 - 2018. Retrieved from http://www.depkop.go.id/uploads/lapora n/1580223129 PERKEMBANGAN\%20 DATA\%20USĀHA\%20MIKRO,\%20KE CIL,\%20MENENGAH\%20(UMKM)\%20 DAN\%20USAHA\%20BESAR\%20(UB)
\%20TAHUN\%202017\%20-

$\% 202018$.pdf on July $10^{\text {th }} 2020$

Lee, B., Park, J., \& Yang, J. S. (2018). Do older workers really reduce firm productivity? The Economic and Labour Relations Review, 29(4), 521-542.

Losby, J. L., Else, J. F., Kingslow, M. E., Edgcomb, E. L., Malm, E. T., \& Kao, V. (2002). Informal economy literature review. ISED Consulting and Research, 1-55.

Montes, J. G. D., Corrales, J., \& Singh, P. (2016). The'informality gap': can education help minorities escape informal employment?: evidence from Peru. IZA Discussion Paper No. 10389

Nackerdien, F., \& Yu, D. (2019). A panel data analysis of the formal-informal sector labour market linkages in South Africa. Development Southern Africa, 36(3), 329-350.

Nilakusmawati, D. P. E., (2009). Kajian Aktivitas Ekonomi Pelaku Sektor Informal di Kota Denpasar (Studi Kasus Wanita Pedagang Canang Sari). Piramida Jurnal Kependudukan Dan Pengembangan Sumber Daya Manusia, 5.

Noeraini, A. A. (2015). Ekonomi Informal di Indonesia, Suatu Tinjauan Pustaka. Sustainable Competitive Advantage (SCA), 5(1).

Omom, P. O. (2017). Urban Informal Sector: How much Women are Struggling for Family Survival. International Journal of Physical and Social Sciences, 7(10), 4054.

Petrova, K. (2019). Globalization and the Informal Economy in Developing Countries. In Globalization and Development (pp. 49-73). Springer, Cham.

Peredo, A. M., \& Chrisman, J. J. (2006). Toward a theory of community-based enterprise. Academy of management Review, 31(2), 309-328.

Pitoyo, A. J. (2007). Dinamika Sektor Informal DI Indonesia Prospek, Perkembangan, dan Kedudukannya dalam Sistem Ekonomi Makro. Populasi, 18(2).

Rogan, Mike \& Cichello, Paul. (2017). Can informal employment actually reduce poverty?. Wiego: Women in Informal Employment Globalizing and Organizing. Retrieved from https://www.wiego.org/blog/caninformal-employment-actually-reduce- 
poverty on July 15 th 2020.

Singh, M. (2009). Social and cultural aspects of informal sector learning: meeting the goals of EFA. In International Handbook of Education for the Changing World of Work (pp. 349-358). Springer, Dordrecht.

Tansel, A., \& Acar, E. O. (2016). The formal/informal employment earnings gap: evidence from Turkey. In Inequality after the 20th Century: Papers from the Sixth ECINEQ Meeting. Emerald Group Publishing Limited.

Taymaz, E. (2009). Informality and productivity: Productivity differentials between formal and informal firms in Turkey. Country Economic Memorandum (CEM)Informality: Causes, Consequences, Policies.

UNDP. (2013). Challenges of the Middle Income Countries: Seoul Debates. Seoul South Korea: United Nations Development Programme.

Uribe J, Ortiz C, García G. 2007. La Segmentación del Mercado Laboral Colombiano en la Década de los Noventa. Revista de Economía Institucional 9(16): 189-221. e, timber and mining (pp. 1-28). IIED Working Paper.

Weng, X. (2015). The rural informal economy: Understanding drivers and livelihood impacts in agricultur Uribe $\mathrm{J}$, Ortiz C. 2006. Informalidad Laboral En Colombia 1988-2000: Evolución, Teorías y Modelos. Programa Editorial Universidad del Valle: Cali-Colombia.

Wijayaningtyas, M., Sipan, I., \& Lukiyanto, K. (2017, November). Informal worker phenomenon in housing construction project. In AIP Conference Proceedings (Vol. 1903, No. 1, p. 070006). AlP Publishing LLC. 